\title{
La toux diabolique: neurogenic tussive crisis
}

\author{
Daniel E. Jacome
}

Departments of Medicine, Palmetto General Hospital and Hialeah Hospital, Hialeah, Florida; and the Department of Neurology, University of Miami School of Medicine, Miami, Florida, USA.

\begin{abstract}
Summary: A 52 year old female non-smoker with multiple sclerosis had a 10 year history of frequent diurnal and nocturnal spontaneous attacks of coughing, relapsing and remitting, with typical symptoms of her illness. Otolaryngeal evaluations failed to show any lesions or vocal cord paresis, and her cardiopulmonary examinations were normal. Her attacks were greatly improved by carbamazepine and valproate sodium. I suggest that tussive crisis constitutes a paroxysmal symptom in multiple sclerosis, amenable to treatment with anticonvulsant agents.
\end{abstract}

\section{Introduction}

Paroxysmal symptoms in multiple sclerosis are distinguishable from the more common transient neurological disturbances, in that they are characteristically frequent, likely to occur during the most active phases of the disease and have abrupt onset and brief duration (Miley \& Forster, 1974). These symptoms include trigeminal neuralgia, paroxysmal pain and itching (Osterman \& Westerberg, 1975), tonic seizures (Matthews, 1958; Joynt \& Green, 1962), akinesia (Castaigne et al., 1970), vertigo (McAlpine et al., 1972), paroxysmal paraesthesias, ataxia and dysarthria (Miley \& Forster, 1974; Osterman \& Westerberg, 1975; Andermann et al., 1959), and paroxysmal hiccuping ('hoquet diabolique') (McFarling \& Susac, 1979). I have seen a patient with multiple sclerosis exhibiting the unusual paroxysmal symptoms of coughing.

\section{Case report}

A 52 year old female consulted the neurologist because of frequent, severe, diurnal and nocturnal spontaneous attacks of unproductive coughing of approximately $10 \mathrm{y}$ duration. The attacks could be innumerable at times and averaged $30 \mathrm{~s}$ to $2 \mathrm{~min}$. She had never smoked and she was unaware of any precipitating factors for her attacks, which were always preceded by a 'tickling' sensation in her throat. The nocturnal crises seriously disturbed her sleep. There were no other respiratory or cardiovascular symptoms. Otolaryngology and pulmonary clinical, endoscopic

Correspondence: D.E. Jacome, M.D., Palmetto General Medical Plaza, Suite 401, 7100 West 20th Avenue, Hialeah, Florida 33016, USA.

Accepted: 11 October 1984 and radiological examinations had failed to show any lesions or vocal cord paresis. Multiple antitussive medications did not control her cough during the years. However, periods of remission of variable duration had occurred, unrelated to medication. The patient had also experienced other simultaneously remitting and relapsing symptoms of slurred speech, swallowing disturbances, imbalance, blurred vision, increased urinary frequency and numbness of her left hand. General physical examination was unremarkable. On neurological examination, visual acuity was $20 / 25$ bilaterally. She had dysarthria because of weakness of the left palate, decreased osteotendinous reflexes, dysmetria of the lower limbs on heel-to-shin testing, ataxic gait and a right Babinski's sign. She also exhibited right hemifacial spasms. Touching the pharynx or nasal mucosa and hyperventilation did not induce coughing, and the gag reflex was normal. Lhermitte's sign was not present. Blood count, plasma biochemistry, urinalysis and thyroid function tests were normal. Lupus cell preparation and syphilis serology were negative. Chest and skull roentgenograms were normal. Pulmonary function tests showed no evidence of obstructive or restrictive lung disease. Electrocardiogram was normal and one twodimensional echocardiogram diagnosed mitral valve prolapse. Electroencephalogram (EEG) and brainstem auditory evoked responses (BAER) were normal. EEG recordings during coughing episodes showed no abnormalities. Visual evoked response (VER) latencies were bilaterally delayed. Computerized tomography of the brain (CT) with detailed views of the posterior fossa was normal. Lumbar puncture revealed normotensive crystal clear cerebrospinal fluid (CSF) with a cell count of 2 lymphocytes $/ \mathrm{mm}^{3}$. CSF protein was $34 \mathrm{mg} / \mathrm{dl}$, glucose $60 \mathrm{mg} / \mathrm{dl}$ (blood sugar $90 \mathrm{mg} / \mathrm{dl}$ ), and CSF protein electrophoresis was nor- 
mal. CSF myelin basic protein was elevated $(4.2 \mathrm{ng} /$ $\mathrm{ml})$.CSF cultures for bacteria and fungi were negative. The patient was placed on oral carbamazepine (200 $\mathrm{mg}$ t.i.d.) with significant improvement of her tussive crisis. However, this medication was discontinued due to intolerable side effects. Oral valproate sodium ( $250 \mathrm{mg}$ q.i.d.) suppressed nocturnal crises and greatly reduced diurnal attacks, and therapeutic plasma levels of this medication were achieved. No progression of her neurological condition has occurred over 16 months follow-up.

\section{Discussion}

Several explanations have classically been advanced to explain the occurrence of paroxysmal symptoms in

\section{References}

ANDERMANN, F., COSGROVE, J.B.R., LLOYD-SMITH, D. \& WALTERS, A.M. (1959). Paroxysmal dysarthria and ataxia in multiple sclerosis. Neurology (Minneapolis), 9, 211.

CASTAIGNE, P., CAMBIER, J., MASSON, M., BRUNET, P., LECHEVALLIER, B., DELAPORTE, P. \& DEHEN, H. (1970). Les manifestations motrices paroxystiques de la sclerose en plaques. Presse Médicale, 78, 1921.

DAVIS, J.N. (1970). An experimental study of hiccup. Brain, 93, 851.

EKBOM, K.A., WESTERBERG, C.E. \& OSTERMAN, P.O. (1968). Focal sensory-motor seizures of spinal origin. Lancet, i, 67.

FARIELLO, R.G. \& MUTANI, R. (1974). Treatment of hiccup. Lancet, ii, 1201.

GUYTON, A.C. (1981). In Textbook of Medical Physiology, Ed. 6, W.B. Saunders Company, Philadelphia.

HARRISON, M. \& MCGILL, J.I. (1969). Transient neurological disturbances in disseminated sclerosis: a case report. multiple sclerosis. These include loss of suprasegmental inhibitory influences (Davis, 1970), neuronal denervation hypersensitivity mechanisms (Castaigne $e t$ al., 1970), build-up of post-synaptic facilitation (Harrison \& McGill, 1969), epileptiform activity (Fariello \& Mutani, 1974), rapidly reversible functional interruption of cerebellar or brainstem tracts (Miley \& Forster, 1974), and transversely ephaptic spreading activation of axons originating from an irritative lesion (plaque) (Ekbom et al., 1968). The cough reflex is mediated by vagal nerve afferents that are integrated at the medullary level (Guyton, 1981). The tickling sensation this patient had in her upper airway could represent a central lesional precipitant sensory reflex component of her crisis (axonal afferent volleys) transversely activating efferent medullary axons involved in the cough reflex.

Journal of Neurology, Neurosurgery and Psychiatry, 32, 230.

JOYNT, R.J. \& GREEN, D. (1962). Tonic seizures as a manifestation of multiple sclerosis. Archives of Neurology, 6, 293.

MCALPINE, D., LUMSDEN, C.E. \& ACHESON, E.D. (1972). In Multiple Sclerosis: A Re-appraisal, 2nd Edition. Churchill Livingstone: Edinburgh and London.

MCFARLING, D.A. \& SUSAC, J.O. (1979). Intractable hiccups as a manifestation of multiple sclerosis. Neurology $(N Y)$ 29, 797.

MATTHEWS, W.B. (1958). Tonic seizures in disseminated sclerosis. Brain, 81, 193.

MILEY, C.E. \& FORSTER, F.M. (1974). Paroxysmal signs and symptoms in multiple sclerosis. Neurology (Minneapolis), 24, 458.

OSTERMAN, P.O. \& WESTERBERG, C.E. (1975). Paroxysmal attacks in multiple sclerosis. Brain, 98, 189. 